\title{
The Impact of Fiscal Expenditures on Vulnerability to Poverty of Rural Households and Its Mechanism-based on Evidence from CHIP Data
}

\section{Qinman Li}

The School of Public Finance and Taxation, Central University of Finance and Economics, Beijing, P. R. China

\section{Email address:}

liqinman627@163.com

\section{To cite this article:}

Qinman Li. The Impact of Fiscal Expenditures on Vulnerability to Poverty of Rural Households and Its Mechanism-based on Evidence from CHIP Data. International Journal of Economics, Finance and Management Sciences. Vol. 8, No. 1, 2020, pp. 20-30.

doi: $10.11648 /$ j.ijefm.20200801.13

Received: December 8, 2019; Accepted: December 27, 2019; Published: January 9, 2020

\begin{abstract}
China's governments at all levels have played a significant role in reducing the absolute poverty through fiscal expenditure arrangements. At present, China has become the country with the strongest efforts and the most significant effect to fight against poverty in the world. However, the governance of poverty is not only simply to solve the existing poverty problem, but should take preventive measures from a certain forward-looking perspective, strengthen the family's ability to resist risks, and reduce the probability of poverty from the root cause. This paper empirically examines the impact of China's fiscal educational expenditure, fiscal social security and employment expenditure, and fiscal health expenditure on vulnerability to poverty of rural households by using the CHIP2013 micro-survey data, and analyzes its mechanisms. The vulnerability value is calculated according to the VEP method, and we identify whether the counties where the households are located are national poverty counties so as to distinguish the effects. The poverty vulnerability level of farmers in national poverty-stricken counties is significantly higher than that of non-poverty-stricken counties. The baseline regression results show that all three kinds of fiscal expenditures can significantly reduce the vulnerability of farmers. Health care expenditure has the strongest effect. Social security and employment expenditure has a stronger effect on the vulnerability of farmers in national poverty-stricken counties than non-poverty-stricken counties. Then, the explained variables are replaced with dummy variables that are vulnerable at $50 \%$ threshold, and the Probit model is used for robustness testing to prove that the baseline regression results are credible. Finally, this paper examines the mechanism by which fiscal expenditure affects the vulnerability of farmers, and verifies that it affects the vulnerability of household poverty by affecting individual employment decisions.
\end{abstract}

Keywords: Vulnerability to Poverty, Fiscal Expenditure, Rural Poverty

\section{Introduction}

Since the reform and opening up, China's poverty alleviation has achieved remarkable achievements. According to the poverty line that 2300 yuan per person per year under 2010 price level, the rural poverty population in China was 770 million in 1978 , and the incidence of poverty was $97.5 \%{ }^{1}$. At the end of 2018 , the rural poor population was 16.6 million,

1 The National Bureau of Statistics. "Significantly Improved the Status of the Country, the International Influence Has Been Significantly Enhanced - the 19th Series of Reports on the Achievements of Economic and Social Development in the 40 Years of Reform and Opening Up ". Retrieved from:

http://www.stats.gov.cn/ztjc/ztfx/ggkf40n/201809/t20180917_1623312.html. and the incidence of poverty was $1.7 \% \%^{2}$. China's governments at all levels have played a significant role in reducing the absolute poverty through fiscal expenditure arrangements. At present, China has become the country with the strongest efforts and the most significant effect to fight against poverty in the world. The report of the 19th National Congress stated that China will eliminate poverty in 2020 and achieve the goal of building a well-off society in an all-round way. However, measurements of absolute poverty, relative poverty, or multidimensional poverty and their improvement methods are

2 National Bureau of Statistics. "Statistical Communiqué on National Economic and Social Development in 2018". Retrieved from:

http://www.stats.gov.cn/tjsj/zxfb/201902/t20190228_1651265.html. 
aimed at the past or current poverty status of poor families, and do not take into account the risks faced by the family's future welfare. Poverty is a dynamic and random phenomenon. Households that have already been out of poverty may fall back into poverty due to external shocks. Non-poor households may also fall into poverty in the future due to certain risks. Therefore, the governance of poverty is not simply to solve the existing poverty problem, but should take preventive measures from a certain forward-looking perspective, strengthen the family's ability to resist risks, and reduce the probability of poverty from the root cause. In recent years, poverty vulnerability has gradually become a hot topic in the field of poverty. Interpreting poverty vulnerability from the perspective of a combination of micro and macro, and grasping the relationship between poverty vulnerability and fiscal policy will not only help reveal the mechanism of poverty occurrence and transmission, but also help to formulate poverty prevention and block long-term poverty. It is helpful to ensure the progress of targeted poverty alleviation in China. Therefore, the purpose of this article is to base on poverty vulnerability theory and make targeted suggestions for fiscal policies in China's poverty governance process. The rest of this article will be arranged as follows. In section 2, we will go through the existed literature to make clear the research directions and progresses. In section 3 , we calculate the value to vulnerability to poverty and briefly describe the current situation. In section 4 and 5 , we test how fiscal expenditures affect vulnerability of households and do some robustness tests. In section 6 , we will test the mechanism of the effects. Finally, we will draw conclusions and provide recommendation.

\section{Literature Review}

The concept of poverty vulnerability was first formally proposed by the World Bank in 2001 (Word Bank, 2001 [1]). The World Bank defines vulnerability as the likelihood that an individual or family will face certain risks for a certain period of time in the future, and that exposure to risks will result in welfare levels such as wealth and quality of life falling below a certain standard. As can be seen from the definition, poverty vulnerability is an ex ante measurement of loss, and its meaning includes the prediction of the degree of loss and the measurement of the ability to respond. Therefore, the size of poverty vulnerability is the result of the game between the probability of loss and the ability to cope (Hu and Yue, 2016 [2]).

Domestic and foreign scholars mainly study the causes, calculations, and influencing factors of poverty vulnerability, of which the latter two are mostly. From the perspective of causes, Zhu and Chen (2018) [3] believe that the external risks faced by the family, their ability to cope with risks (internal risks), and the actions taken ultimately together lead to the consequences of vulnerability. According to the combing of the existing literature, the definition and measurement methods of vulnerability are roughly classified into three types. The first is the Vulnerability as Expected Poverty (VEP) proposed by Chaudhuri et al. (2002) [4]. Under this theory, vulnerability is seen as the possibility that the family will fall into poverty in the future. The second is the Vulnerability as Low Expected Utility (VEU) proposed by Ligon and Schechter (2003) [5]. They thought of vulnerability as the difference between the utility of deterministic equivalent consumption levels and the expected utility of household consumption. The third is the Vulnerability as Uninsured Exposure to Risk (VER) proposed by Dercon and Krishnan (2000) [6]. Under this theory, vulnerability is a decline in the level of consumption of households when they are exposed to risk.

Domestic scholars mostly studied the influencing factors of poverty vulnerability from the perspective of sustainable livelihood and precise poverty alleviation. Scholars analyzed the influencing factors of rural vulnerability in the current perspective of precision poverty alleviation, and put forward long-term suggestions for the policies and systems of dynamic poverty governance in China. It is advocated that in the theory and practice of targeted poverty alleviation in China's rural areas, vulnerability should be incorporated into the dynamic theory of poverty. By setting the poverty vulnerability line, combining individual life cycle analysis, and in accordance with the different characteristics of poverty vulnerability to address rural vulnerable poverty (Luo and Chen, 2017 [7]). To improve the effectiveness of anti-poverty, we must start with reducing the vulnerability of farmers, combine anti-poverty with building a well-off society and structural reforms on the agricultural supply side, and restructure the precise poverty alleviation system from multiple levels (Wang et al., 2017 [8]). The relationship between the environment and poverty should be handled properly, avoiding falling into the "poverty trap", actively carrying out multiple poverty alleviation efforts, focusing on improving the family's livelihood capabilities, implementing targeted poverty alleviation projects, and encouraging farmers to find alternative living capital conversion capabilities (Wei and Luo, 2018 [9]). Some studies analyzed the role of poverty alleviation policies such as financial education and employment poverty alleviation on vulnerability to poverty. $\mathrm{Li}$ et al. (2010) [10] found that amilies with similar vulnerabilities may have different root causes of fragility and should be classified for assistance and suggested that measures to reduce vulnerability should focus on increasing income levels, such as improving education, organizing training, reducing taxes and exemptions, and transferring payments. Xie et al. (2019) [11] found that fiscal education policies can effectively alleviate long-term poverty and reduce the probability that children generation will fall into poverty in the future, reduce intergenerational transmission of poverty. Xie and Ding (2019) [12] found that participating migrant workers significantly reduced the vulnerability level of the total sample, and that migrant workers were superior to local migrant workers in reducing poverty vulnerability. They proposed to further implement industrial supporting policies, promote employment 
poverty alleviation, and promote the development of labor markets in rural areas, so as to achieve poverty alleviation. Besides, based on the analysis of sustainable livelihood, Chen (2018) [13] examined the negative causal relationship between the new generation of migrant workers' livelihood capital and poverty vulnerability, and found that human capital is most effective in reducing the vulnerability to poverty, followed by natural capital, material capital, and social capital. Feng et al. (2018) [14] constructed the poverty vulnerability index of farmers from the framework of "risk-living capital-adaptive ability" and found that farmers who lacked multiple capitals had the highest risk. From the perspective of single capital, the degree of vulnerability that caused by lack of human capital is the highest, followed by financial capital, physical capital and natural capital.

In terms of the influencing factors of poverty vulnerability, it can be roughly summarized into three perspectives: public, private, and risk shock. First, from a public perspective, scholars have explored the role of factors such as supply of public goods (Li and Cai, 2014 [15]), public transfer payment (Fan and Xie, 2014 [16]), social assistance system such as medical assistance and minimum living guarantee (Zhang and Shen, 2014 [17]; Xu and Li, 2017 [18]), New rural social endowment insurance (Li and Xi, 2015 [19]; Shen and Guo, 2018 [20]), financial governance (Xiong and Chen, 2013; Zhang and Yin, 2018 [22]), social support network (Xu et al., 2011 [23]; Li et al., 2011 [24]; Hu and Yue, 2016 [25]), open trade (Lin and Deng, 2014 [26]) on vulnerability to poverty. Second, from a private perspective, the existing literature analyzes the effects of factors such as human capital like education and health (Huang, 2013 [27]), labor work (Tai et al., 2009 [28]; Gao and $\mathrm{Li}, 2018$ [29]), rural migrant workers entrepreneurship (Xu and Gong, 2017 [30]), assets (Wan et al., 2014 [31]), and private transfer payment (Xie et al., 2015 [32]) on poverty vulnerability. Third, in terms of risk impact, Zhang and Zhuang (2011) [33] studied the impact of natural disasters on the vulnerability to poverty of farmers. It is recommended that the government vigorously develop infrastructure construction and improve the level of protection, thereby improving farmers' ability to cope with the impact of natural disasters. Mahanta and Das (2017) [34] studied the impact of shock factors such as floods on poverty vulnerability and found that the vulnerability of most households was affected by shocks.

Through the combing of the existing literature, we can find that there is no shortage of discussion on the vulnerability of poverty in China, and there are already many articles on the role and path of fiscal policy on poverty. However, whether fiscal policy can effectively reduce the poverty vulnerability of families, as well as its mechanism of action and direction of improvement, remains to be verified in detail.

\section{The Measurement of Poverty Vulnerability}

\subsection{Measuring Method}

This paper learns from Chauhuri et al. (2002) VEP measurement method for poverty vulnerability, and predicts the probability of future poverty by estimating the mean and variance of future income. By definition, the basic measure of poverty vulnerability can be expressed as:

$$
V_{h, t}=\operatorname{Pr}\left(Y_{h, t+1} \leq Z\right)
$$

That is, the size of poverty vulnerability is the probability that the family's income in the next period will be lower than a certain poverty line. Among them, $V_{h, t}$ represents the level of poverty vulnerability of family h during period t. $Y_{h, t+1}$ is the family's per capita income level during period $t+1$. $Z$ indicates a specific limit. Usually, most of the existing literature use the poverty line standard of 1 US dollar, 1.25 US dollars, and 2 US dollar per person per day.

According to the establishment of the welfare production function and the availability of data by the existing scholars, we set the welfare level $Y_{h}$ of the farmer $h$ to be determined by the characteristics of the farmer's individual and the farmer's community. The welfare production function of the farmer is expressed as:

$$
\ln Y_{h, t}=X_{h}^{\prime} \beta_{1}+M_{h}^{\prime} \beta_{2}+\varepsilon_{h}
$$

Where $X_{h}$ is the vector of individual characteristics of the farmer, $\mathrm{M}_{\mathrm{h}}$ is the vector of the community characteristics where the farmer is located. $\beta_{1}$ and $\beta_{2}$ are the parameters to be estimated. $\varepsilon_{h}$ is a disturbance item with a mean of zero, which can capture the trait factors (such as shock) that cause the family's per capita income level to be different.

In the form of the probability density function of income, some scholars use the Bootstrap Method to fit. However, the premise of adopting this method is to obtain observable family characteristics and income in the past, so as to generate specific density function (Kamanou et al. 2002 [35]; Kühl, 2003 [36]). Most scholars directly assume that the household future consumption or income is log-normally distributed (Chaudhuri et al., 2002; Rajadel, 2002 [37]; Christiaensen and Subbarao, 2005 [38]). This paper chooses to directly assume that future income follows a log-normal distribution, that is $\ln Y_{h, t+1} \sim N\left(\mu_{\ln Y_{h, t+1}}, \sigma_{\ln Y_{h, t+1}}^{2}\right)$. Then we can get the probability density function of income:

$$
f\left(\ln Y_{h, t+1}\right)=\frac{1}{\sigma_{h} \sqrt{2 \pi}} e^{-\left(\ln Y_{h, t+1}-\mu_{h}\right) / 2 \sigma_{h}^{2}}
$$

Therefore, the vulnerability to poverty can be expressed as: 


$$
V_{h, t}=\operatorname{Pr}\left(\ln Y_{h, t+1} \leq \ln Z\right)=\int_{-\infty}^{\text {poor }} f_{t}\left(\ln Y_{h, t+1}\right) d\left(Y_{h, t+1}\right)=\Phi\left(\frac{\ln Z-\mu_{h}}{\sigma_{h}}\right)
$$

Where $\Phi(\cdot)$ represents the cumulative distribution function of the standard normal distribution.

In reality, the condition that the logarithm function of each farmer's welfare is homoskedasticity is difficult to achieve. We assume that the household welfare dissipative item $\varepsilon_{h}$ has heterogeneity related to the characteristics of the farmer, and the variance is:

$$
\sigma_{\varepsilon, h}^{2}=X_{h}^{\prime} \theta_{1}+M_{h}^{\prime} \theta_{2}
$$

In the presence of heteroskedasticity, the parameters estimated by the least squares method will be biased. Therefore, the parameters $\beta_{1}, \beta_{2}, \theta_{1}, \theta_{2}$ are estimated by the three-stage feasible generalized least squares (FGLS) method that was adopted by Chaudhuri et al.

The first stage is to return the income equation through the OLS method, namely equation (2), to obtain the average income:

$$
E\left[\ln Y_{h, t} \mid X_{h}, M_{h}\right]=X_{h}^{\prime} \hat{\beta}_{1}+M_{h}^{\prime} \hat{\beta}_{2}
$$

In the second stage, the residual squared delivered by the first stage is used to represent the fluctuation of income. The variance model is obtained by the OLS equation, and the income is assumed to follow log-normal distribution, so as to obtain the heteroskedastic structure. In the third stage, we use the weighted regression WLS and the obtained heteroskedastic structure to estimate the parameters.

$$
\begin{array}{r}
\hat{V}\left[\ln Y_{h} \mid X_{h}, M_{h}\right]=\hat{\sigma}_{\varepsilon, h}^{2}=X_{h}^{\prime} \hat{\theta}_{1}+M_{h}^{\prime} \hat{\theta}_{2} \\
\hat{\mathrm{V}}_{\mathrm{h}, \mathrm{t}}=\Phi\left(\frac{\ln Z-X_{h}^{\prime} \hat{\beta}_{1}-M_{h}^{\prime} \hat{\beta}_{2}}{\sqrt{X_{h}^{\prime} \hat{\theta}_{1}+M_{h}^{\prime} \hat{\theta}_{2}}}\right)
\end{array}
$$

\subsection{Selection of Vulnerability Threshold and Poverty Line}

In the estimation process, we draw on the method adopted by most scholars in the past to set a moderate vulnerability threshold of 0.5 and a high vulnerability threshold of 0.75 (Wan and Zhang, 2009; Fan and Xie, 2014; Li and Cai, 2014; Xie and Ding, 2019). At present, the national poverty line is the absolute poverty line of 2,300 yuan in 2010 , which is equivalent to the standard of 2013, which is 2,567 yuan. We choose daily $\$ 1, \$ 2$ per capital and national poverty line as the boundary $\mathrm{Z}$ in equation (1). (Under the length limit, this article does not show the regression results of the calculation process).

Figure 1 shows the number of households with poverty vulnerability when setting different vulnerability thresholds under the three poverty lines. As the threshold increases, the number of vulnerable households decreases.

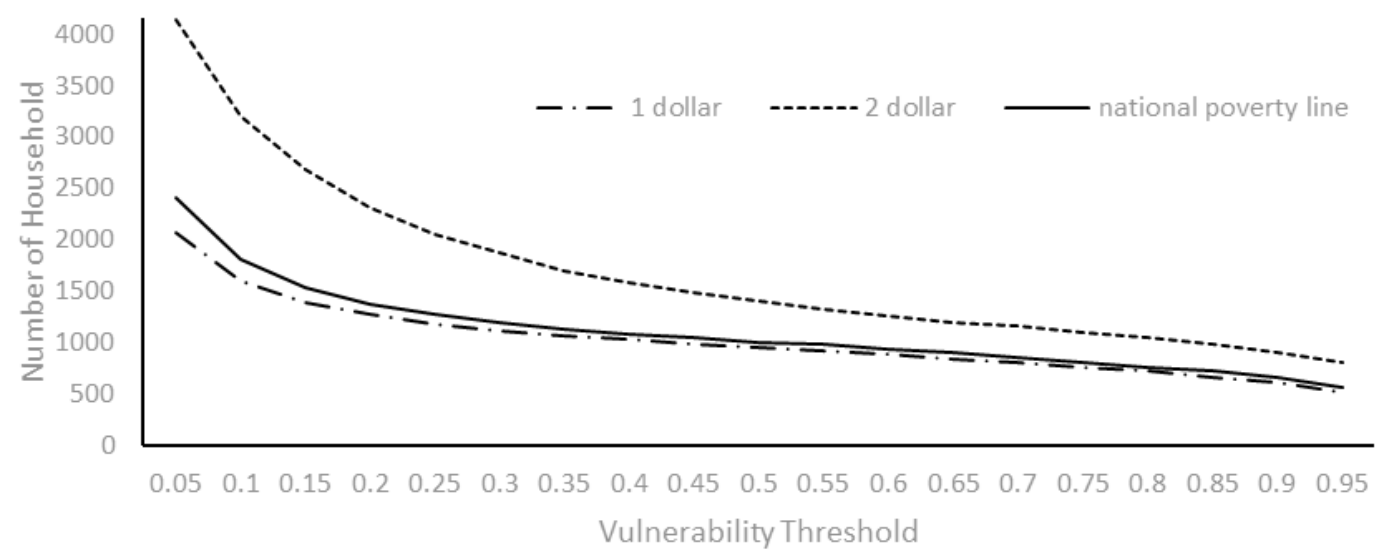

Figure 1. Farmers' Poverty Vulnerability Under Three Poverty Lines.

Poverty vulnerability of the sample is shown in Table 1 . The data shows that under the three poverty lines, the proportion of households in the national poverty-stricken counties with moderate and high levels of poverty vulnerability is significantly higher than that of non-poverty-stricken counties. Take China's poverty alleviation line as an example. About $28 \%$ of the samples in poverty-stricken counties are moderately vulnerable (vulnerability level is greater than 50\%), and about
$26 \%$ are severely vulnerable (vulnerability level is greater than $75 \%$ ), while less than $10 \%$ of households samples in non-poverty-stricken counties are moderately vulnerable. The average vulnerability of households in national poverty-stricken counties is higher than that in non-poverty-stricken counties, which proves to a certain extent that households with higher levels of poverty are also more vulnerable to poverty. 
Table 1. Poverty Vulnerability of Samples in Poverty-Stricken and Non-Poverty-Stricken Counties Under Three Poverty Lines.

\begin{tabular}{|c|c|c|c|c|c|c|c|}
\hline & & \multicolumn{2}{|l|}{ All Samples } & \multicolumn{2}{|c|}{ Poverty Counties } & \multicolumn{2}{|c|}{ Non-Poverty Counties } \\
\hline & & Proportion & Average & Proportion & Average & Proportion & Average \\
\hline \multirow{2}{*}{1 dollar } & Vulnerability (50\%) & $11.2 \%$ & 0.8855 & $27.45 \%$ & 0.9293 & $8.78 \%$ & 0.8650 \\
\hline & Vulnerability (75\%) & $8.89 \%$ & 0.9525 & $25 \%$ & 0.9556 & $6.48 \%$ & 0.9507 \\
\hline \multirow{2}{*}{2 dollar } & Vulnerability (50\%) & $16.57 \%$ & 0.8845 & $37.27 \%$ & 0.9088 & $13.48 \%$ & 0.8745 \\
\hline & Vulnerability (75\%) & $13 \%$ & 0.9587 & $31.18 \%$ & 0.9650 & $10.29 \%$ & 0.9558 \\
\hline National & Vulnerability (50\%) & $11.86 \%$ & 0.8924 & $28 \%$ & 0.9360 & $9.44 \%$ & 0.8731 \\
\hline Poverty Line & Vulnerability (75\%) & $9.58 \% \%$ & 0.9535 & $26 \%$ & 0.9582 & $7.12 \%$ & 0.9510 \\
\hline
\end{tabular}

\section{Data Source, Related Processing, and Variable Description}

\subsection{Data Source and Processing}

The data used in this study is from the 2013 China Household Income Survey (CHIP) data set. The survey covered 18,948 household samples and 64,777 individual samples from 234 districts and counties in 126 cities in 15 provinces. Because the national poverty alleviation policy targets rural poor groups, this paper selects 11,013 rural household samples. Municipal fiscal education expenditure, fiscal social security and employment expenditure, and fiscal health expenditure data are from the CEIC database, which is matched with micro-individuals according to the national statistical bureau's municipal code. At the same time, we looked up the list of national poverty-stricken counties updated in 2012, and matched them with micro data according to the county code of the National Bureau of Statistics, so as to distinguish whether the effects on samples from national poverty-stricken counties are significantly different from non-poverty-stricken counties. The poverty line of daily US\$1 and US\$2 per capita selected in this paper is converted into RMB through the exchange rate of the US dollar in 2013. According to the 2010 constant price of 2,300 yuan, the poverty line is converted into the 2013 price level through three years of inflation. Fiscal expenditures in previous years are converted to 2013 price levels through CPI. Poverty vulnerability is measured by households. Therefore, some indicators use the average household level. Some indicators use information of head of household. After processing and screening out the invalid samples, the final sample is 8858 farmers.

\subsection{Variable Description}

In the process of studying the fiscal expenditures on vulnerability to the poverty of farmers, the explained variable is measured by the poverty line of 2300 yuan expressed in China's 2010 constant price. The specific calculation process is shown in the third part of this paper. The core explanatory variables are fiscal education expenditure, fiscal social security and employment expenditure, and fiscal health expenditure.

Table 2. Descriptive Statistics of the Main Variables.

\begin{tabular}{|c|c|c|c|c|c|}
\hline Variable Name & Variable Label & Variable Description & Number of samples & Mean & Standard deviation \\
\hline $\begin{array}{l}\text { Logarithm of household } \\
\text { income per capita }\end{array}$ & $\ln Y$ & In (household income per capita) & 8811 & 9.1889 & 0.7529 \\
\hline $\begin{array}{l}\text { Poverty vulnerability } \\
\text { (Poverty Alleviation } \\
\text { Line) }\end{array}$ & $\mathrm{V}$ & $\begin{array}{l}\text { Vulnerability calculated by using the per } \\
\text { capita net income of } 2,300 \text { yuan per year in } \\
2010 \text { as the poverty line. }\end{array}$ & 8459 & 0.1369 & 0.2905 \\
\hline $\begin{array}{l}\text { Logarithm of financial } \\
\text { education expenditure }\end{array}$ & lnfinedu & $\begin{array}{l}\text { The logarithm of the fiscal education } \\
\text { expenditure of the city where the sample is } \\
\text { located. }\end{array}$ & 8858 & 8.5045 & 0.6331 \\
\hline $\begin{array}{l}\text { Logarithm of fiscal social } \\
\text { security and employment } \\
\text { expenditure }\end{array}$ & lnfinwelf & $\begin{array}{l}\text { The logarithm of fiscal social security and } \\
\text { employment expenditure in the city where the } \\
\text { sample is located. }\end{array}$ & 8049 & 8.0893 & 0.5705 \\
\hline $\begin{array}{l}\text { Logarithm of fiscal } \\
\text { health expenditure }\end{array}$ & lnfinmed & $\begin{array}{l}\text { The logarithm of fiscal health expenditure in } \\
\text { the city where the sample is located. }\end{array}$ & 8858 & 7.6816 & 0.5568 \\
\hline $\begin{array}{l}\text { National poverty } \\
\text { counties }\end{array}$ & poverty & $\begin{array}{l}\text { Whether the county where the sample is } \\
\text { located is the key development county for } \\
\text { national poverty alleviation. (If it is, the value } \\
\text { is } 1 \text {, otherwise the value is } 0 \text { ) }\end{array}$ & 8854 & 0.1323 & 0.3388 \\
\hline Logarithm of GDP & lngdp & $\ln (\mathrm{GDP})$ & 8118 & 3.6241 & 0.5943 \\
\hline Years of education & eduyear & $\begin{array}{l}\text { Number of years of individual formal } \\
\text { education (excluding skip and repeat years) }\end{array}$ & 8610 & 7.1731 & 2.6555 \\
\hline Health level & health & $\begin{array}{l}\text { Compared with their peers, the respondents } \\
\text { thought they were in a good state of health ( } 1 \\
\text { is very good, } 2 \text { is good, } 3 \text { is general, } 4 \text { is bad, } \\
5 \text { is very bad) }\end{array}$ & 8846 & 2.1916 & 0.9482 \\
\hline Disabled & disable & $\begin{array}{l}\text { Whether the individual is disabled. (Dummy } \\
\text { variable, if he/she is disabled, the value is } 1 \text {, } \\
\text { otherwise is } 0 \text { ) }\end{array}$ & 8824 & 0.0565 & 0.2310 \\
\hline Medical insurance & medicare & Whether the household participates in any & 8854 & 0.9709 & 0.1682 \\
\hline
\end{tabular}




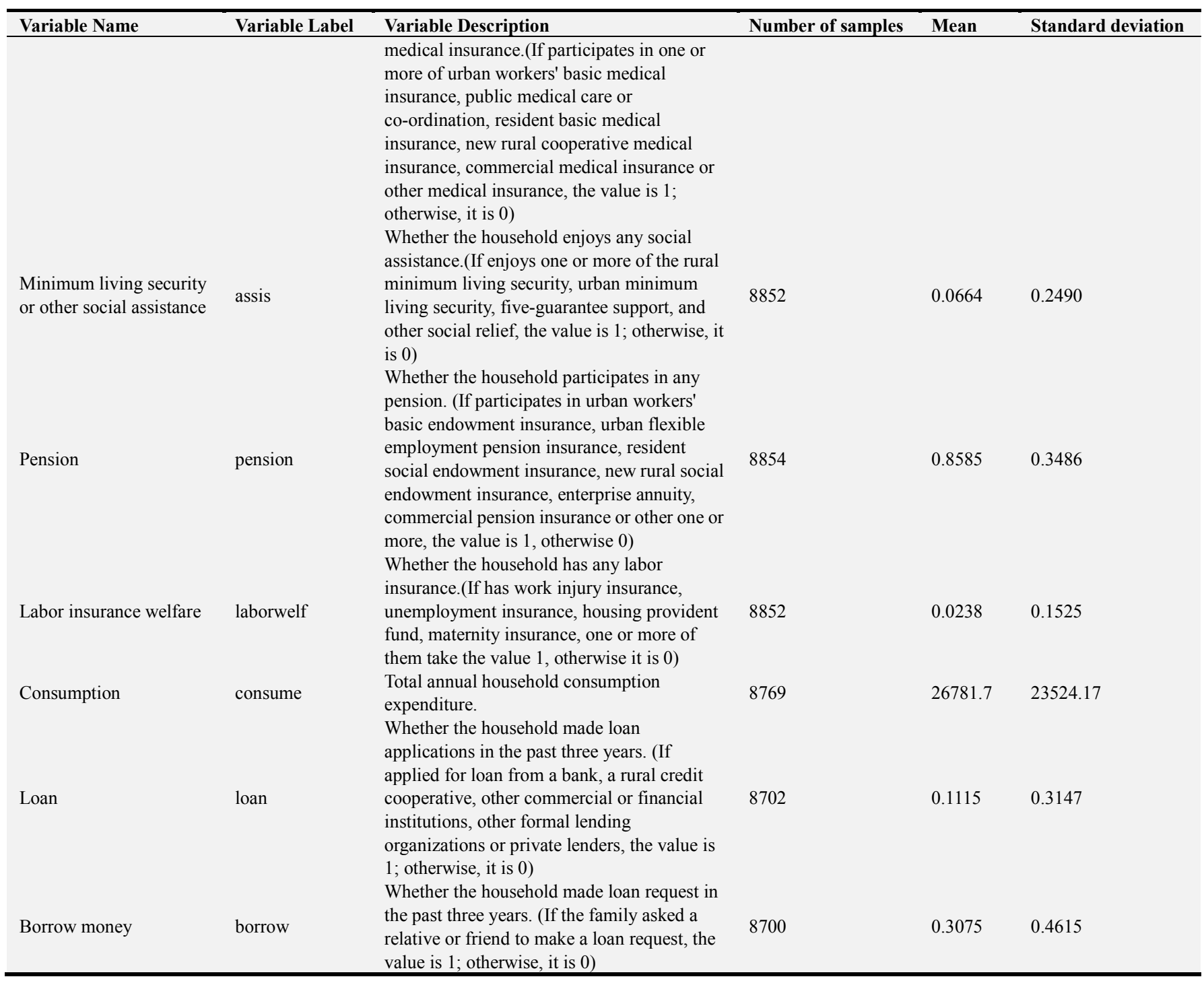

Data source: CHIP2013 and CEIC database.

\section{Empirical Results and Robustness}

\section{Tests}

\subsection{Benchmark Regression of Fiscal Expenditure and Poverty Vulnerability}

Many existing literatures proved that fiscal education expenditure, fiscal social security and employment expenditure, and fiscal medical and health expenditure can effectively increase household income per capita levels and improve income poverty in the long run. But can fiscal spending reduce the poverty vulnerability of households? In the following parts of this sector, we use the poverty vulnerability that calculated in part III of this article as the explained variable, the three types of fiscal expenditures as the core explanatory variables, controlling regional GDP per capita, whether located in a national poverty-stricken county, and household and individual characteristic variables at the same time.
Table 3. Fiscal Expenditure and Vulnerability to Poverty.

\begin{tabular}{llll}
\hline & Model 1 & Model 2 & Model 3 \\
\hline Infinedu & $-0.0491^{* * *}$ & & \\
& $(0.0053)$ & & \\
poverty & $-6.1428^{* * *}$ & $6.0036^{* * *}$ & -0.3449 \\
& $(0.4125)$ & $(0.4639)$ & $(0.2921)$ \\
lnfinedu*poverty & $0.7667^{* * *}$ & & \\
& $(0.0504)$ & & \\
lnfinwelf & & $-0.0460^{* * *}$ & \\
& & $(0.0063)$ & \\
lnfinwelf*poverty & & $-0.7173^{* * *}$ & \\
lnfinmed & & $(0.0572)$ & \\
& & & $-0.0785^{* * *}$ \\
lnfinmed*poverty & & & $(0.0061)$ \\
& & & $0.0746^{*}$ \\
lnrjgdp & & $(0.0386)$ \\
eduyear & $(0.0063)$ & $(0.0061)$ & $(0.0057)$ \\
& $-0.0102^{* * *}$ & $-0.0108^{* * *}$ & $-0.0109^{* * *}$ \\
health & $(0.0013)$ & $(0.0014)$ & $(0.0013)$ \\
disable & $-0.0271^{* * *}$ & $-0.0290^{* * *}$ & $-0.0284^{* * *}$ \\
\hline
\end{tabular}




\begin{tabular}{llll}
\hline & Model 1 & Model 2 & Model 3 \\
\hline & $(0.0181)$ & $(0.0192)$ & $(0.0189)$ \\
medicare & $-0.4693^{* * *}$ & $-0.4846^{* * *}$ & $-0.4670^{* * *}$ \\
& $(0.0270)$ & $(0.0281)$ & $(0.0269)$ \\
assis & $-0.0435^{* * *}$ & $-0.0629^{* * *}$ & $-0.0606^{* * *}$ \\
& $(0.0126)$ & $(0.0144)$ & $(0.0138)$ \\
pension & $0.0369^{* * *}$ & $0.0583^{* * *}$ & $0.0484^{* * *}$ \\
& $(0.0093)$ & $(0.0106)$ & $(0.0095)$ \\
laborwelf & -0.0455 & 0.0159 & -0.0069 \\
& $(0.0323)$ & $(0.0342)$ & $(0.0299)$ \\
consume & $-6.58 \mathrm{e}^{-07 * * *}$ & $-6.43 \mathrm{e}^{-07 * * *}$ & $-6.63 \mathrm{e}^{-07 * * *}$ \\
& $\left(1.34 \mathrm{e}^{-07}\right)$ & $\left(1.45 \mathrm{e}^{-07}\right)$ & $\left(1.33 \mathrm{e}^{-07}\right)$ \\
loan & -0.0085 & $-0.0226^{* *}$ & $-0.0303^{* * *}$ \\
& $(0.0104)$ & $(0.0115)$ & $(0.0110)$ \\
borrow & $0.0440^{* * *}$ & $0.0521^{* * *}$ & $0.0463^{* * *}$ \\
& $(0.0074)$ & $(0.0081)$ & $(0.0075)$ \\
constant & $1.1044^{* * *}$ & $1.1369^{* * *}$ & $1.2543^{* * *}$ \\
& $(0.0479)$ & $(0.0563)$ & $(0.0543)$ \\
\hline
\end{tabular}

Note: Standard deviations in parentheses. ${ }^{*}, * *, * *$ indicate significant levels at $10 \%, 5 \%$ and $1 \%$ respectively.

Model 1 to Model 3 respectively reflect the impacts of education, social security and employment, and health expenditures on poverty vulnerability. All three types of expenditures have significant negative effects on the poverty vulnerability of farmers, that is, fiscal expenditure helps to reduce the poverty vulnerability of farmers. From the value of the estimated coefficient, the fiscal medical and health expenditure improves the farmer's vulnerability the most, and a $1 \%$ increase in the city's medical and health expenditure can reduce the poverty vulnerability of rural households by $7.85 \%$. The theory of poverty vulnerability argues that the vulnerability of households mainly comes from risks. Poverty caused by illness and returning to poverty due to illness has always been the most important reason for the poverty problems, ranking first among many causes of poverty. Increasing fiscal expenditure on health care can provide residents with medical health protection to a certain extent and enhance their ability to resist disease risks. Besides, every $1 \%$ increase in municipal education expenditure can improve the poverty vulnerability of farmers in non-poverty-stricken counties by $4.91 \%$; every $1 \%$ increase in municipal social security and employment spending can reduce the poverty vulnerability of farmers in non-poverty-stricken counties by $4.6 \%$. The reduction effects of fiscal education expenditure and fiscal medical expenditure on the vulnerability of farmers in national poverty-stricken counties is smaller compared to non-poverty-stricken counties, and even fiscal education expenditure can increase the vulnerability of households in national poverty-stricken counties. The fiscal social security and employment expenditure makes greater efforts to improve the vulnerability of farmers in national poverty-stricken counties.

\subsection{Robustness Test}

This article establishes a dummy variable of poverty vulnerability. If the vulnerability of farmers is greater than $50 \%$, it is considered to be vulnerable and assigned the value to be 1 ; if it is less than $50 \%$, it is assigned to equal 0 . This dummy variable is used to replace the degree of vulnerability in the previous step as the explained variable. All other variables are unchanged. The Probit model is used to test the robustness of the improvement effects of the three fiscal expenditures on poverty vulnerability. As shown in Table 5, Model 4 to Model 6 respectively represent the test models that use fiscal education, social security and employment, and health care expenditures as the core explanatory variables. The results show that the impact of the three types of expenditure on the poverty vulnerability of rural households is still significantly negative. Medical and health fiscal expenditure has the greatest effect. The effect of social security and employment fiscal expenditure on improving poverty vulnerability of farmers is stronger in national poverty counties than in non-poverty counties. It can be seen that the results obtained by the baseline regressions are robust.

Table 4. Fiscal Expenditure and "Whether Vulnerable".

\begin{tabular}{|c|c|c|c|}
\hline & Model 4 & Model 5 & Model 6 \\
\hline Infinedu & $\begin{array}{l}-0.2828^{* * *} \\
(0.0361)\end{array}$ & & \\
\hline poverty & $\begin{array}{l}-19.22^{* * *} \\
(1.5723)\end{array}$ & $\begin{array}{l}23.3501^{* * *} \\
(2.5574)\end{array}$ & $\begin{array}{l}-0.4561 \\
(1.2550)\end{array}$ \\
\hline lnfinedu*poverty & $\begin{array}{l}2.3985^{* * *} \\
(0.1894)\end{array}$ & & \\
\hline lnfinwelf & & $\begin{array}{l}-0.2707^{* * *} \\
(0.0441)\end{array}$ & \\
\hline Infinwelf*poverty & & $\begin{array}{l}-2.8202^{* * *} \\
(0.3214)\end{array}$ & \\
\hline lnfinmed & & & $\begin{array}{l}-0.4426^{* * *} \\
(0.0405)\end{array}$ \\
\hline Infinmed*poverty & & & $\begin{array}{l}0.1603 \\
(0.1663)\end{array}$ \\
\hline lnrjgdp & $\begin{array}{l}-0.1089^{* *} \\
(0.0424)\end{array}$ & $\begin{array}{l}-0.2431^{* * *} \\
(0.0412)\end{array}$ & $\begin{array}{l}-0.0705^{*} \\
(0.0399)\end{array}$ \\
\hline eduyear & $\begin{array}{l}-0.0017 \\
(0.0091)\end{array}$ & $\begin{array}{l}-0.0024 \\
(0.0094)\end{array}$ & $\begin{array}{l}-0.0053 \\
(0.0091)\end{array}$ \\
\hline health & $\begin{array}{l}-0.0522^{*} \\
(0.0285)\end{array}$ & $\begin{array}{l}-0.0587^{* * *} \\
(0.0289)\end{array}$ & $\begin{array}{l}-0.0602^{* *} \\
(0.0285)\end{array}$ \\
\hline disable & $\begin{array}{l}-0.0808 \\
(0.1295)\end{array}$ & $\begin{array}{l}-0.0020 \\
(0.1293)\end{array}$ & $\begin{array}{l}0.0158 \\
(0.1274)\end{array}$ \\
\hline medicare & $\begin{array}{l}-1.9164^{* * *} \\
(0.1155)\end{array}$ & $\begin{array}{l}-1.9724^{* * *} \\
(0.1238)\end{array}$ & $\begin{array}{l}-1.9053^{* * *} \\
(0.1160)\end{array}$ \\
\hline assistance & $\begin{array}{l}-0.2584^{* * *} \\
(0.0993)\end{array}$ & $\begin{array}{l}-0.3363^{* * *} \\
(0.1030)\end{array}$ & $\begin{array}{l}-0.3596^{* * *} \\
(0.1004)\end{array}$ \\
\hline pension & $\begin{array}{l}0.1930^{* * *} \\
(0.0643)\end{array}$ & $\begin{array}{l}0.2763^{* * *} \\
(0.0693)\end{array}$ & $\begin{array}{l}0.2548^{* * *} \\
(0.0653)\end{array}$ \\
\hline laborwelf & $\begin{array}{l}-0.4122^{*} \\
(0.2366)\end{array}$ & $\begin{array}{l}-0.0435 \\
(0.2285)\end{array}$ & $\begin{array}{l}-0.1436 \\
(0.2052)\end{array}$ \\
\hline consume & $\begin{array}{l}-7.53 \mathrm{e}^{-06 * * *} \\
\left(1.58 \mathrm{e}^{-06}\right)\end{array}$ & $\begin{array}{l}-7.13 \mathrm{e}^{-06 * * *} \\
\left(1.61 \mathrm{e}^{-06}\right)\end{array}$ & $\begin{array}{l}-7.49 \mathrm{e}^{-06^{* * *}} \\
\left(1.58 \mathrm{e}^{-06}\right)\end{array}$ \\
\hline loan & $\begin{array}{l}-0.0516 \\
(0.0607)\end{array}$ & $\begin{array}{l}-0.0191^{*} \\
(0.0631)\end{array}$ & $\begin{array}{l}-0.1497^{* *} \\
(0.0625)\end{array}$ \\
\hline borrow & $\begin{array}{l}0.2413^{* * *} \\
(0.0419)\end{array}$ & $\begin{array}{l}0.2596^{* * *} \\
(0.0434)\end{array}$ & $\begin{array}{l}0.2425^{* * *} \\
(0.0415)\end{array}$ \\
\hline constant & $\begin{array}{l}3.4584^{* * *} \\
(0.3337)\end{array}$ & $\begin{array}{l}3.7606^{* * *} \\
(0.4088)\end{array}$ & $\begin{array}{l}4.2919^{* * *} \\
(0.3670)\end{array}$ \\
\hline
\end{tabular}

Note: Standard deviations in parentheses. *, **,*** indicate significant levels at $10 \%, 5 \%$ and $1 \%$ respectively.

In addition, we also replace the explained variables with 
poverty vulnerability values measured with the poverty line at US $\$ 1$ and US $\$ 2$, and the results also confirm that the baseline regressions are robust. Due to space limitations, the regression results are not shown one by one.

\section{Mechanism Examination}

Next, we further examine the mechanism of fiscal expenditures affecting the vulnerability to poverty of rural households. According to the theory of sustainable livelihoods, the core contents of its analysis are livelihood capital, livelihood capabilities, and livelihood strategies. The CHIP survey data is not a questionnaire designed for the topic of this article, there are great limitations in variables, and the variables that can reflect livelihood capital and livelihood capabilities are insufficient. Therefore, this article only explores from the path of livelihood strategy to check whether it is one of the mechanisms by which fiscal expenditure reduces the vulnerability of farmers. First, this article takes all micro-individuals as samples, and uses the Probit model to test whether fiscal expenditure has a positive impact on individual employment decisions and decisions that whether migrant to work. We then use households level as samples to test whether the increase in the proportion of employed persons and migrant workers in a family will reduce the poverty vulnerability of the family.

\subsection{Impact of Fiscal Expenditures on Individual Livelihood Strategies}

In the first step, this paper selects the dummy variables of whether individuals aged 18-60 are employed and whether they are migrant workers as the explained variables, and three types of fiscal expenditures are used as explanatory variables, so as to test whether fiscal expenditures affect individual employment decisions. Model 10-Model 12 are the results of the effects of fiscal expenditures on individual employment. All three fiscal expenditures positively affect individual employment probability. Models 13 to Model 14 show the effects of fiscal expenditures on out-of-town employment. The results show that the three types of fiscal expenditures also significantly increase the probability of out-of-town employment.

Table 5. Fiscal Expenditures and Employment Decisions.

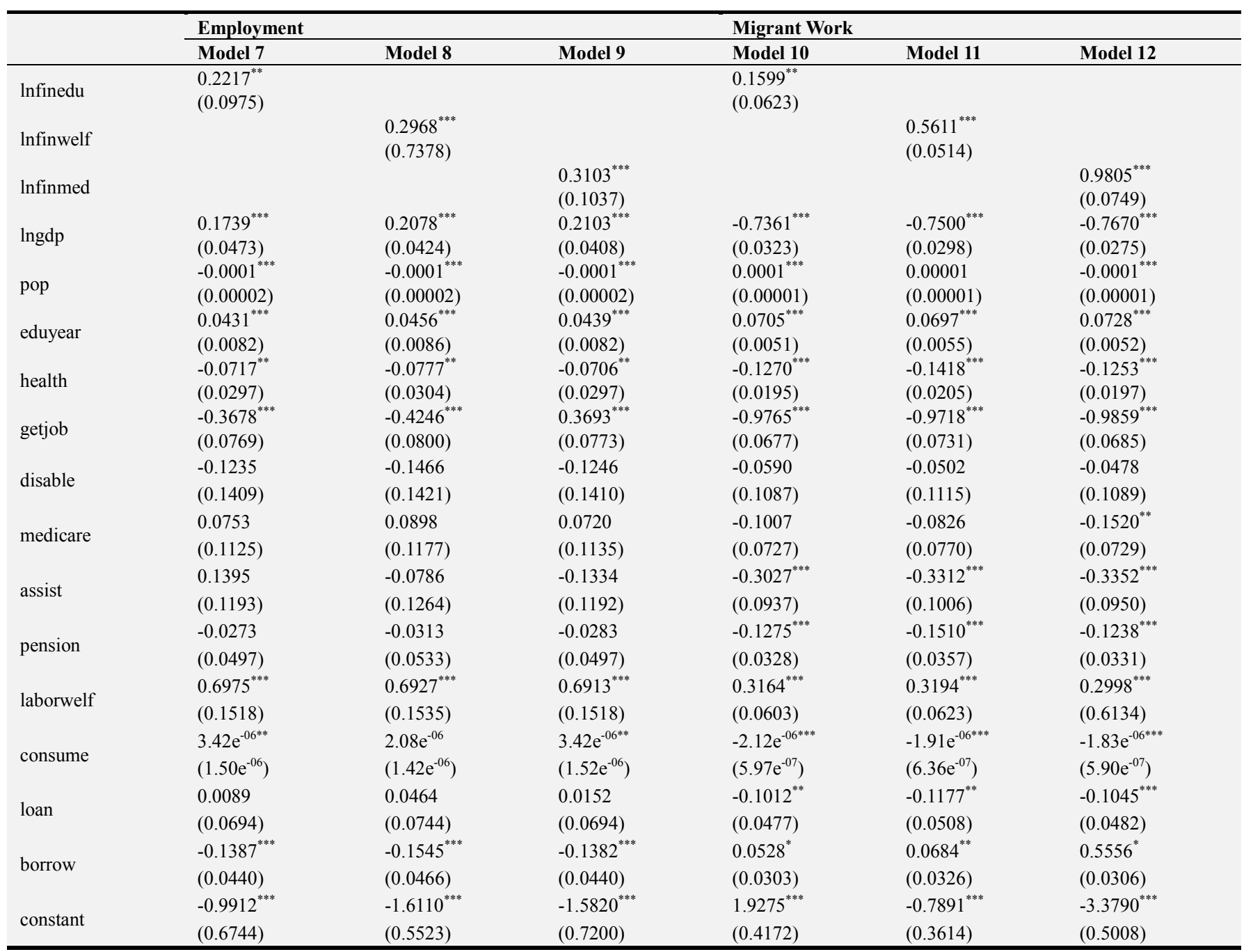

Note: Standard deviations in parentheses. $*, * * * * *$ indicate significant levels at $10 \%, 5 \%$ and $1 \%$ respectively. 


\subsection{Impact of Family Livelihood Strategies on Vulnerability to Poverty}

In the second step, this article uses the poverty vulnerability calculated in section III as the explained variable, and uses the proportion of employed members (Model13) and the proportion of migrant workers (Model14) as explanatory variables in order to study the impact on employment decisions on households' vulnerability. The results show that the representative variables of both employment decisions significantly reduce the vulnerability of rural households, and the role of migrant workers is greater. Therefore, we conclude that fiscal expenditures can affect the level of poverty vulnerability of farmers by changing individual employment and migrant work decisions.

Table 6. Livelihood Decisions and Poverty Vulnerability of Farmers.

\begin{tabular}{lll}
\hline & Model 13 & Model 14 \\
\hline $\begin{array}{l}\text { employment } \\
\text { migrant }\end{array}$ & $-0.0404^{* * *}(0.0107)$ & \\
lngdp & & $-0.0463^{* * *}(0.0144)$ \\
pop & $-0.0526^{* * *}(0.0060)$ & $-0.0571^{* * *}(0.0061)$ \\
eduyear & $-3.51 \mathrm{e}^{-06^{*}}\left(2.02 \mathrm{e}^{-06}\right)$ & $-2.62 \mathrm{e}^{-06}\left(2.03 \mathrm{e}^{-06}\right)$ \\
health & $-0.0108^{* * *}(0.0015)$ & $-0.0110^{* * *}(0.0015)$ \\
disable & $-0.0247^{* * *}(0.0047)$ & $-0.0249^{* * *}(0.0047)$ \\
medicare & $-0.0273(0.0220)$ & $-0.0239(0.0219)$ \\
assis & $-0.4723^{* * *}(0.0225)$ & $-0.4743^{* * *}(0.0225)$ \\
pension & $-0.0397^{* * *}(0.0167)$ & $-0.0408^{* *}(0.0167)$ \\
laborwelf & $0.0525^{* * *}(0.0101)$ & $0.0489^{* * *}(0.0100)$ \\
consume & $0.0422(0.0328)$ & $0.0440(0.0329)$ \\
loan & $-6.26 \mathrm{e}^{-07 * * *}\left(1.43 \mathrm{e}^{-07}\right)$ & $-6.08 \mathrm{e}^{-0 . * * *}\left(1.43 \mathrm{e}^{-07}\right)$ \\
borrow & $-0.0179^{*}(0.0104)$ & $-0.0203^{*}(0.0104)$ \\
constant & $0.0520^{* * *}(0.0071)$ & $0.0529^{* * *}(0.0071)$ \\
\hline
\end{tabular}

Note: Standard deviations in parentheses. ${ }^{*}, * *, * *$ indicate significant levels at $10 \%, 5 \%$ and $1 \%$ respectively.

\section{Conclusions and Policy Recommendations}

\subsection{Conclusions}

Based on VEP theory, using the CHIP2013 micro-survey data, the poverty vulnerability of farmers is calculated under the three poverty lines of US \$1, US \$2, and 2010 constant price of 2,300 yuan. We conduct an overall assessment of vulnerability and explore the impact of municipal fiscal education expenditure, social security and employment expenditure, and medical and health expenditure on farmers' vulnerability to poverty. We find that: (1) The vulnerability results measured by selecting different poverty lines are different. As the poverty line standards increase, the values of vulnerability to poverty also increase. (2) The proportion of moderately and highly vulnerable farmers in national poverty-stricken counties is higher than in non-poverty-stricken counties, and the average vulnerability level of farmers in national poverty-stricken counties is higher than that in non-poverty-stricken counties. It can be seen that families with high levels of poverty are also more vulnerable.
(3) All three types of fiscal expenditures have significantly alleviated the vulnerability of farmers, of which medical and health expenditure has the greatest effect. (4) The effect of fiscal social security and employment expenditure on easing the poverty vulnerability of farmers in national poverty-stricken counties is greater than that of farmers in non-poverty-stricken counties, while the effects of education and health expenditure on farmers in national poverty-stricken counties are weakened.

Then we verify the mechanism of "fiscal expenditure-livelihood strategy-vulnerability to poverty". The regression results of the Probit models show that all three fiscal expenditures significantly increase the probability of individuals' decision of employment and migrant to work between the ages of 18-60. Both of the proportion of employed members and the proportion of migrant workers in rural households have significantly alleviated the vulnerability of farmers.

\subsection{Recommendations}

Based on the conclusions above, we make the following suggestions. First, we propose to increase fiscal education, social security and employment, and medical and health expenditures to alleviate the vulnerability of rural households. Since all of the three types of fiscal spending has positive effects on farmers' vulnerability to poverty, governments should invest relevant expenditures within its own feasible capacity to promote China's efforts to fight poverty. Second, We suggest that governments optimize the structure of fiscal expenditure, both among different types of expenditures and within one type. The effect of social security and employment fiscal expenditure is relatively direct and obvious, and is stronger in national poverty-stricken counties. On one hand, governments need to make sure that relevant government spending can keep protecting the social safety net, which is the last net to prevent people fall into the poverty line. On the other hand, governments should actively play the role of public finance to promote employment. For residents in poor areas, we should provide vulnerable families more social security and employment-related public goods and services. Finances should stimulate the employment willingness of the labor force among farmers, promote out-of-town employment and other forms of non-agricultural employment to reduce the vulnerability of families, so as to inspire the poor to secure the future through their own efforts. Third, We also recommend that governments pay more attention to rural education development, especially in deeply impoverished area. As Amartya Sen's viewpoint of "ability poverty", people in poor area generally lack of opportunities to reach education of knowledge and skills, which in turn leads to low ability to maintain livelihood, which in turn leads to low capability to resist and prevent risks. Therefore, in the process of advancing the equalization of public services for education, fiscal expenditure should be appropriately tilted towards the poor and vulnerable. Although evidence shows that the effect in deeply poverty area is not obvious in short 
run, it is a long-term courseware process and cannot be ignored. Fourth, we suggest that governments pay more attention to health and medical development in rural area. As we know, difficult and expensive medical treatment is a basic reason for "poverty due to illness". Further guarantee the coverage of rural residents by education expenditure and health care expenditure, and ensure that rural groups can benefit from them. Fifth, governments should vigorously encourage social organizations to participate in the poverty governance process through fiscal and tax policies. Local governments face multiple fiscal pressures. And to some extent, governments' ability and professional in specific fields are difficult to guarantee. Participation of social organizations can alleviate the financial pressure and improve the professionalism of poverty governance in different fields.

\section{References}

[1] World Bank (2001). World development report 2000/2001: attacking poverty. World Bank Publications, 39 (6), 1145-1161.

[2] Hu, J., \&Yue J. (2016). Research on Rural Poverty Vulnerability and Its Social Support Networ. Administrative forum, 2016, 23 (03): 19-23.

[3] Zhu, J., \&Chen, L. (2018). Formation Mechanism and Poverty Reduction Strategy of Poverty Vulnerability. Learning and Practice, 2018 (12): 103-110.

[4] Chaudhuri, S., Jalan, J., \& Suryahadi, A. (2002). Assessing household vulnerability to poverty from cross-sectional data: A methodology and estimates from Indonesia.

[5] Ligon, E., \& Schechter, L. (2003). Measuring vulnerability. The Economic Journal, 113 (486), C95-C102.

[6] Dercon, S., \& Krishnan, P. (2000). Vulnerability, seasonality and poverty in Ethiopia. The Journal of Development Studies, $36(6), 25-53$

[7] Luo, R., \&Chen, J. (2017). Rural Vulnerability, Poverty Dynamics and Governance in the Perspective of Precision Poverty Alleviation — A Case Study of Tibetan Rural Communities. Finance Science, 2017 (01): 93-104.

[8] Wang, G., Zhang, N., \& Yang, Y. (2017). Deconstruction of Poverty Vulnerability and Reconstruction of Precision Poverty Alleviation System — Based on Western Rural Areas. Social Science Research, 2017 (05): 67-76.

[9] Wei, H., \& Luo, W. (2018). Analysis of Farmers' Livelihood Vulnerability and Influencing Factors from the Perspective of Precision Poverty Alleviation-Based on Empirical Investigation in Poor Areas of Gansu Province. Journal of Henan Normal University (Philosophy and Social Sciences), 2018, 45 (02): 65-71.

[10] Li, L., \& Liu, Y. (2010). Research on Poverty Alleviation Policy from the Perspective of Vulnerability. Public Finance Research, 2010 (09): 58-62.

[11] Xie, Y., Xie, E., \& Qu, Y. (2019). Does Fiscal Education Policy Alleviate Long-term Poverty? — A Perspective Based on Poverty Vulnerability. Journal of Shanghai University of Finance and Economics, 2019, 21 (03): 4-17.
[12] Xie, Y., \& Ding, F. (2019). Research on the Impact of Employment Poverty Alleviation from the Perspective of Poverty Vulnerability. Journal of Shanghai University of Finance and Economics, 2019, 21 (03): 18-32.

[13] Chen, C. (2018). Evaluation of Poverty Vulnerability of New Generation Migrant Workers in Western China_-Based on the Investigation of Livelihood Capital. Journal of Southwest University for Nationalities (Humanities and Social Sciences), 2018, 39 (05): 127-132.

[14] Feng, J., et al. (2018). A Study on the Vulnerability of Poor Farmers Based on the Framework of Sustainable Livelihood Analysis: A Case Study of Pingshang Village, Yi County, Gansu Province. Chinese Journal of Eco-Agriculture, 2018, 26 (11): 1752-1762.

[15] Li, L., \& Cai, C. (2014). Research on the Supply of Rural Public Goods from the Perspective of Poverty Vulnerability. Public Finance Research, 2014 (01): 25-28.

[16] Fan, L., \& Xie, E. (2014). Do Public Transfers Reduce Poverty Vulnerai 'bility? Economic Research Journal, 2014, 49 (08): 67-78.

[17] Zhang, X., \& Shen, W. (2014). Research on the Alleviation Effect of Medical Assistance on Poverty Vulnerability of Low-income Families. Dongyue Tribune, 2014, 45 (08).

[18] Xu, C., \& Li, L. (2017). Whether Urban and Rural Dibao Guarantees Help Future Poverty Reduction: An Empirical Analysis Based on Poverty Vulnerability. Finance \& Trade Economics, 2017, 38 (05): 5-19+146.

[19] Li, Q., \& Xi, H. (2015). Impact of New Rural Insurance on Family Poverty Vulnerability: A Study Based on Chinese Family Tracking Survey Data. Shanghai Journal of Economic, 2015 (07): 46-54.

[20] Shen, B., \& Guo, Z. (2018). Does the New Rural Insurance Improve the Vulnerability of Rural Low-income Families? B Based on a Staged Analysis. Chinese Rural Economy, 2018 (01): 90-107.

[21] Xiong, N., \& Chen, C. (2013). An Empirical Study on Rural Financial Governance of Farmers' Vulnerable Poverty_Evidence from CHNS Data. Wuhan Finance, 2013 (02): 51-54.

[22] Zhang, D., \& Yin, Z. (2018). Financial Inclusion, Risk Response and Poverty Vulnerability of Rrural Households. Chinese Rural Economy, 2018 (04): 54-73.

[23] Xu, W., et al. (2011). Social Networks and Poverty Vulnerability: An Empirical Analysis Based on Chinese Rural Data. Academia Bimestris, 2011 (04): 122-128.

[24] Li, B., et al. (2011). The Impact of Changes in Social Relation Networks on Poverty Vulnerability of Rural Households: An Empirical Study with Changgang Village in Hubei Province as an Example. Rural Economy, 2011 (03): 100-103.

[25] Hu, J., \& Yue, J. (2016). Research on Rural Poverty Vulnerability and Its Social Support Network. Administrative Tribune, 2016, 23 (03): 19-23.

[26] Lin, W., \& Deng, M. (2014). Does Trade Openness Affect China's Rural Poverty Vulnerability: An Empirical Analysis Based on CHNS Microdata. Journal of International Trade, 2014 (06): 23-32. 
[27] Huang, X. (2013). To What Extent Health Leads to Poverty Vulnerability: an Empirical Analysis Based on CHNS Rural Data. Statistics \& Information Forum, 2013, 28 (09): 54-62.

[28] Tai, X., et al. (2009). The Impact of Migrant Workers on Poverty Vulnerability: Evidence from Rural Households in Western Mountain Areas. World Economic Forum, 2009 (06): 67-76.

[29] Gao, R., \& Li, S. (2017). Is the Rural Labor Force Going Out Helping Left-behind Families to Get Out of Poverty? — An Empirical Analysis Based on the Poverty Vulnerability Method. Journal of Beijing Normal University (Social Sciences), 2018 (04): 132-140.

[30] Xu, C., \& Gong, B. (2017). Has Farmer Entrepreneurship Reduced Poverty Vulnerability. Modern Finance \& Economic (Journal of Tianjin University of Finance and Economics), 2017, 37 (05): 46-59.

[31] Wan, G., et al. (2014). Decomposition of Poverty Vulnerability from the Perspective of Assets: An Empirical Analysis Based on Panel Data of Chinese Farmers. Chinese Rural Economy, 2014 (04): 4-19.

[32] Xie, E. (2015). Intergenerational Upward Private Transfers and Poverty Vulnerability. Economic Management Journal, 2015, 37 (03): 170-179.
[33] Zhang, G., \& Zhuang, T. (2011). Impact of Natural Disasters on Poverty Vulnerability of Rural Households — Based on the Empirical Analysis of Yunnan Province in 2009. Journal of Sichuan Agricultural University, 2011, 29 (01): 136-140.

[34] Mahanta, R., \& Das, D. (2017). Flood induced vulnerability to poverty: evidence from Brahmaputra Valley, Assam, India. International journal of disaster risk reduction, 24, 451-461.

[35] Kamanou, G., \& Morduch, J. (2002). Measuring vulnerability to poverty (No. 2002/58). WIDER Discussion Papers//World Institute for Development Economics (UNU-WIDER).

[36] Kühl, J. J. (2003). Disaggregating household vulnerabilityanalyzing fluctuations in consumption using a simulation approach. Manuscript, Institute of Economics, University of Copenhagen, Denmark.

[37] Rajadel, T. (2002). Vulnerability and Participation to the Non-Agricultural Sector in Rural Pakistan. TEAM Working Paper. Paris: TEAM, Université Paris.

[38] Christiaensen, L. J., \& Subbarao, K. (2005). Towards an understanding of household vulnerability in rural kenya. Policy Research Working Paper, 14 (4), 520-558. 